\title{
11: 112851091-112785527
}

National Cancer Institute

\section{Source}

National Cancer Institute. 11:112851091-112785527. NCI Thesaurus. Code C42149.

Physical location of DRD2_Gene 